\title{
Microbiological and physical-chemical characteristics of the water used to Tambaqui Colossoma macropomum species, in Maranhão State
}

\author{
Características microbiológicas e físico-químicas da água utilizada na criação de \\ peixes da espécie tambaqui “Colossoma macropomum”, na Baixada Maranhense
}

\author{
CUNHA, Maria Cecília de Sousa ${ }^{1}$; COSTA, Ana Cristina Vieira ${ }^{2}$; BOOR, Márcia \\ Araújo Vander ${ }^{3}$; COSTA, Francisca Neide ${ }^{1^{*}}$
}

\author{
${ }^{1}$ Universidade Estadual do Maranhão, Centro de Ciências Agrárias, Departamento de Patologia, \\ Maranhão, Brasil. \\ ${ }^{2}$ Universidade Estadual do Maranhão, Maranhão, Brasil. \\ ${ }^{3}$ Fundação Nacional de Saúde, São Luís, Maranhão, Brasil. \\ *Endereço para correspondência: francisca.cca.uema@gmail.com
}

\section{SUMMARY}

Brazil has favorable hydrographic and climatic conditions for the development of fish farming. The success of this activity depends on the quality of the water, since it directly influences its productivity. Therefore, in order to verify the microbiological and physico - chemical characteristics of the water in the creation of the tambaqui (Colossoma macropomum) species in fish farming in São Bento, a municipality located in the. State, 16 water samples from six fish farms were evaluated for the physical parameters (Temperature, transparency, dissolved oxygen, $\mathrm{pH}$, turbidity, color, alkalinity, hardness, nitrate and nitrite) and microbiological (coliforms and heterotrophic mesophilic bacteria). According to the findings, all samples were contaminated by total and thermotolerant coliforms, 13 (77.15\%) were outside the standards recommended by the legislation. As for the mesophilic aerobic heterotrophic bacteria, the mean counts ranged from $30.6 \times 102$ to $4.7 \times 104 \mathrm{CFU} / \mathrm{mL}$. As for the physical-chemical parameters, it was verified that the temperature ranged from $27.4^{\circ} \mathrm{C}$ to $30^{\circ} \mathrm{C}$; PH 5.0 to 8.2; Transparency ranged from 0 to 46 $\mathrm{cm}$; Turbidity from 12 to $1,251 \mathrm{NTU}$, the color from 0 to $666.50 \mathrm{UH}$; Dissolved oxygen from 7.1 to $14.7 \mathrm{mg} / \mathrm{L}$; Alkalinity of 17.5 to $412 \mathrm{mg} / \mathrm{L}$; Hardness from 14.6 to $1027.8 \mathrm{mg} / \mathrm{L}$; Nitrate from 1 to $160 \mathrm{mg} / \mathrm{L}$ and nitrite from 0.01 to 0.45 $\mathrm{mg} / \mathrm{L}$. The findings show that the water of fish farms has inadequate microbiological and physico-chemical characteristics for fish farming.

Keyword: alkalinity, coliforms, fish farm, turbidity

\section{RESUMO}

O Brasil possui condições hidrográficas e climáticas favoráveis para o desenvolvimento da piscicultura. O sucesso dessa atividade depende da qualidade da água, visto que esta influencia diretamente em sua produtividade. Portanto, com o objetivo de verificar as características microbiológicas e físico - químicas da água na criação da espécie tambaqui (Colossoma macropomum) em piscicultura de São Bento, município localizado na Baixada Maranhense, foram avaliadas 16 amostras de água de seis pisciculturas quanto aos parâmetros físicoquímicos (temperatura, transparência, oxigênio dissolvido, $\mathrm{PH}$, turbidez, cor, alcalinidade, dureza, nitrato e nitrito) e microbiológicos (coliformes e bactérias heterotróficas mesófilas). Conforme os achados, todas as amostras estavam contaminadas por coliformes totais e termotolerantes, sendo que $13(77,15 \%)$ estavam fora dos padrões recomendados pela legislação. Quanto às bactérias heterotróficas aeróbias mesófilas, os valores médios das contagens variaram de $30,6 \times 10^{2}$ a 4,7 x $10^{4} \mathrm{UFC} / \mathrm{mL}$. Quanto aos parâmetros físicoquímicos, verificou-se que a temperatura variou de $27,4{ }^{\circ} \mathrm{C}$ a $30^{\circ} \mathrm{C}$; $\mathrm{pH}$ de 5,0 a 8,2 ; transparência variou de 0 a $46 \mathrm{~cm}$; turbidez de 12 a $1.251 \mathrm{UNT}$, a cor de 0 a 666,50 UH; oxigênio dissolvido de 7,1 a $14,7 \mathrm{mg} / \mathrm{L}$; alcalinidade de 17,5 a $412 \mathrm{mg} / \mathrm{L}$; dureza de 14,6 a 1027,8 mg/L; nitrato de 1 a 160 $\mathrm{mg} / \mathrm{L}$ e nitrito de 0,01 a $0,45 \mathrm{mg} / \mathrm{L}$. Os achados evidenciam que a água das pisciculturas investigadas apresenta características microbiológicas e físico-químicas inadequadas para criação de peixes.

Palavra-chave: alcalinidade, coliformes, piscicultura, turbidez 


\section{INTRODUÇÃO}

In 2010, aquaculture production in Brazil is 479,399 tons, representing an increase of $15.3 \%$ in relation to the production of 2009. Comparing the production with the amount produced in $2008,365,366 \mathrm{t}$, it is evident the growth of the area in the country, with a $31.2 \%$ increase in production, which came mainly from continental fish farming (MPA, 2010).

Fish farming corresponds to 483,241 tonnes of total aquaculture production, with the main species of fish cultivated in the country being tilapia (Oreochromis $\mathrm{sp}$ ), the carp (Cyprinus carpio), the tambaqui (Colossoma macropomum), the tambacu (Colossoma macropomum + Piaractus mesopotamicus and the pacu (Piaractus mesopotamicus). The former corresponds to $45.4 \%$ of national fish production (IBGE, 2016).

The economic success of this activity depends on the monitoring of the main physical-chemical and microbiological variables of water, as well as aquatic life, in order to minimize the impact of human interference on water quality. The activity of creating aquatic organisms in the national territory is promising and care for the environment provides better quality production.

Therefore, the objective of the research was to know the microbiological (coliforms and mesophilic heterotrophic bacteria) and physical chemical characteristics (Temperature, transparency, dissolved oxygen, $\mathrm{pH}$, turbidity, color, alkalinity, hardness, nitrate and nitrite) of fish pond nurseries located in São Bento, in the countryside of Maranhão State.

\section{MATERIAL AND METHODS}

The research was carried out in the period from March to June of 2010 in the municipality of São Bento (Latitude: $02^{\circ}$ 41' 45" S / Longitude: 44 49' 17" W), western part of Maranhão countryside MA, where a survey and registration of properties was carried out, selecting 16 nurseries, distributed in six properties, denominated properties A, B, C, D, E and $F$ each one with $5,4,2,2,2$ e 1 , respectively, numbers of nurseries containing adult fish.

Sixteen samples of water from the nurseries were collected in duplicate, at a depth of $20 \mathrm{~cm}$ below the surface, using sterile flasks. The samples were obtained biweekly and transported in isothermal boxes containing ice to the Food and Water Microbiology Laboratory of the State University of Maranhão, where they were analyzed for microbiological parameters, according to APHA (2001) and the Laboratory of the National Health Foundation (FUNASA), in which the physico-chemical analyzes were performed according to the methodology of Standard Methodes for the examination of water and waste water (2001). The parameters evaluated were: temperature (using mercury thermometer); $\mathrm{pH}$ (using hth test kit for pool); Dissolved oxygen (using digital oximeter Instrutherm PH-1500); Turbidity (verified using turbidimeter AP 2000 IR $n^{\circ}$ 012); Transparency (the Secchi Disc was used); Color (using photometer HI-93727 color); Analyzes of total alkalinity and total hardness by titration were also performed; Nitrite and Nitrate by spectrophotometer. The results obtained were compared with those in the literature and based on standards recommended by current legislation, CONAMA (2005), such as: Total and thermotolerant coliforms 
(maximum of 1000 NMP of coliforms / $100 \mathrm{~mL}$ of water for use in fish culture); Turbidity (for class II waters - for protection of aquatic communities, aquaculture and fishing activity are 100 UNT); The favorable concentrations of dissolved oxygen for fish culture are 5 $\mathrm{mg} / \mathrm{L}$ of water; nitrite level does not exceed $0,5 \mathrm{mg} / 1$; nitrate, for Class II waters (maximum $10 \mathrm{mg} / \mathrm{L}$ ).

\section{RESULTS AND DISCUSSION}

According to the data presented in Table 1, it was verified that of the 16 water samples of the evaluated nurseries, all were contaminated by total and thermotolerant coliforms, 13 (77.15 $\%$ ) of the samples were outside the standards recommended by CONAMA (2005), which admits the maximum of 1000 NMP of coliforms / $100 \mathrm{~mL}$ of water for use in fish culture. It was verified that the total and thermotolerant Coliform counts were higher in properties $\mathrm{B}, \mathrm{C}$ and $\mathrm{F}$, with values $\geq$ 1,600 NMP / $100 \mathrm{ml}$ in all samples analyzed. It can also be highlighted that in the E-property, a variation of 1600 to $\geq 1,600 \mathrm{NMP} / 100 \mathrm{~mL}$ of coliforms was observed. These high contaminations can be related to the origin of the water used in the nurseries, which come from natural ponds, where there are predominant animals such as buffalo, horses, swine and cattle, grazing in these natural environments, excreting feces and urine in these waters, as may also be due to the existence of pits near the nurseries.

Table 1. NMP counts of total coliforms, thermotolerant coliforms and heterotrophic bacteria in 16 water samples from the fish farms of the municipality of São Bento - MA, 2010

\begin{tabular}{|c|c|c|c|c|}
\hline \multirow{2}{*}{ Properties } & \multirow{2}{*}{ Samples } & \multicolumn{2}{|c|}{ Coliforms (NMP/100mL) } & \multirow{2}{*}{$\begin{array}{l}\text { Heterotrophic bactéria } \\
(\mathrm{UFC} / \mathrm{ml})^{* *}\end{array}$} \\
\hline & & Total & Thermotolerant & \\
\hline \multirow{5}{*}{ A } & $\overline{\mathrm{P}_{1}}$ & $\geq 1,6 \times 10^{3} *$ & $\geq 1,6 \times 10^{3} *$ & $22,54 \times 10^{4}$ \\
\hline & $\mathrm{P}_{2}$ & $\geq 1,6 \times 10^{3} *$ & $\geq 1,6 \times 10^{3} *$ & $16,25 \times 10^{2}$ \\
\hline & $\mathrm{P}_{3}$ & $5,4 \times 10^{2}$ & $5,4 \times 10^{2}$ & $4 \times 10^{3}$ \\
\hline & $\mathrm{P}_{4}$ & $\geq 1,6 \times 10^{3} *$ & $\geq 1,6 \times 10^{3} *$ & $25,25 \times 10^{2}$ \\
\hline & $\mathrm{P}_{5}$ & $5,4 \times 10^{2}$ & $5,4 \times 10^{2}$ & $25,75 \times 10^{2}$ \\
\hline \multirow{4}{*}{ B } & $\mathrm{P}_{1}$ & $\geq 1,6 \times 10^{3} *$ & $\geq 1,6 \times 10^{3} *$ & $8 \times 10^{4}$ \\
\hline & $\mathrm{P}_{2}$ & $\geq 1,6 \times 10^{3} *$ & $\geq 1,6 \times 10^{3} *$ & $39,466 \times 10^{3}$ \\
\hline & $\mathrm{P}_{3}$ & $\geq 1,6 \times 10^{3} *$ & $\geq 1,6 \times 10^{3} *$ & $22,116 \times 10^{3}$ \\
\hline & $\mathrm{P}_{4}$ & $\geq 1,6 \times 10^{3} *$ & $\geq 1,6 \times 10^{3} *$ & $25,6 \times 10^{2}$ \\
\hline \multirow{2}{*}{$\mathrm{C}$} & $\mathrm{P}_{1}$ & $\geq 1,6 \times 10^{3} *$ & $\geq 1,6 \times 10^{3} *$ & $25,6 \times 10^{2}$ \\
\hline & $\mathrm{P}_{2}$ & $\geq 1,6 \times 10^{3} *$ & $\geq 1,6 \times 10^{3} *$ & $35,61 \times 10^{2}$ \\
\hline \multirow{2}{*}{$\mathrm{D}$} & $\mathrm{P}_{1}$ & $9 \times 10^{2}$ & $9 \times 10^{2}$ & $14,15 \times 10^{3}$ \\
\hline & $\mathrm{P}_{2}$ & $\geq 1,6 \times 10^{3} *$ & $\geq 1,6 \times 10^{3} *$ & $14,45 \times 10^{3}$ \\
\hline \multirow{2}{*}{ E } & $\mathrm{P}_{1}$ & $\geq 1,6 \times 10^{3} *$ & $\geq 1,6 \times 10^{3} *$ & $2,4 \times 10^{4}$ \\
\hline & $\mathrm{P}_{2}$ & $1,6 \times 10^{3} *$ & $1,6 \times 10^{3} *$ & $7 \times 10^{3}$ \\
\hline $\mathrm{F}$ & $\mathrm{P}_{1}$ & $\geq 1,6 \times 10^{3} *$ & $\geq 1,6 \times 10^{3} *$ & $5,93 \times 10^{3}$ \\
\hline
\end{tabular}

* Samples outside the standards recommended by CONAMA (2005).

$* * \mathrm{UFC} / \mathrm{mL}=$ Colony Forming Units per milliliter. 
These findings are worrying because the high concentrations of coliforms found in the water of the nurseries, together with the gastrointestinal tract and the skin of the fish, show the need for greater care in handling the fish during the slaughter and processing stages, due to the risk of crosscontamination.

Similar results were found by Lorenzon et al. (2010), who found total coliform values ranging from $4.2 \times 104$ to $>2.4 \times$ 105 NMP.100 mL-1, and for thermotolerant coliforms from $1.7 \times 102$ to $9.4 \times 103$ CFU. $100 \mathrm{~mL}-1$ of water.

As regards the counts of mesophilic aerobic heterotrophic bacteria, it was verified according to Table 1 that the minimum value obtained among the 16 samples was $16.25 \times 102$, and the maximum count was 22.54 x 104 $\mathrm{CFU} / \mathrm{mL}$. These high counts corroborate with the data found for total and thermotolerant coliforms, as observed in Table 1.

Therefore, in nurseries with counts above $104 \mathrm{CFU} / \mathrm{mL}$, there may be a risk of pathogens contaminating fish musculature. It is worth noting that in the nurseries evaluated, the water renewal was not carried out for almost two years, therefore these pathogens may have increased with the time of contact of these fish with contaminated water. Although some data from the present study are below $104 \mathrm{CFU} / \mathrm{mL}$, it is important that good practices have to be adopted during the handling of the fish from these nurseries, because there is a possibility of increasing these bacteria along the production chain. These results were also higher than those of Silva (2010), who found counts of $102 \mathrm{CFU} / \mathrm{mL}$ at 104 $\mathrm{CFU} / \mathrm{mL}$ in water analyzes of tambaqui nurseries. Although the legislation for aquaculture waters does not determine the counts of mesophilic heterotrophic bacteria as a quality parameter, it was based on the recommendation of Enactment No. 518 (BRASIL, 2004) for water for human consumption. Analyzing the obtained data, according to the standards of the referred decree, it was verified that all the samples evaluated 16 $(100 \%)$ exceeded the limit of 500 $\mathrm{CFU} / \mathrm{mL}$ recommended by the Brazilian legislation.

As for the physical-chemical parameters, it can be seen from the data in Table 2 that the temperature of the nurseries ranged from $27.4{ }^{\circ} \mathrm{C}$ to $30{ }^{\circ} \mathrm{C}$. These values are considered favorable for tambaqui cultures (Colossoma macropomum), since the ideal temperature for this species is $26^{\circ} \mathrm{C}$ to $28^{\circ} \mathrm{C}$

Regarding to the $\mathrm{pH}$ values, there was a variation from 5.0 to 8.2. The value found in property $A(8.2)$ can be attributed to the growth of a large biological production of phytoplankton and other aquatic vegetables, which remove $\mathrm{CO} 2$ from water through the process of photosynthesis, which increases the $\mathrm{pH}$ of water. In property $\mathrm{B}, \mathrm{pH} 5.0$ is probably related to the decrease or nonexistence of biological products due to the presence of suspended solids in the water, preventing the penetration of the solar rays, which are responsible for the growth of phytoplankton. In this case Boyd (1990) stated that the lethal points of acidity and alkalinity for the fish are $\mathrm{pH}$ values equal to 4 and $\mathrm{pH} \mathrm{11,} \mathrm{respectively.} \mathrm{Thus,} \mathrm{the}$ nurseries of fish farms $\mathrm{B}$ and $\mathrm{C}$, present inadequate $\mathrm{pH}$ for fish farming.

The values referring to the water transparency of the nurseries were at least 0 and maximum $46 \mathrm{~cm}$, the latter indicates a shortage of phytoplankton in the water. In property B it was not possible to measure the transparency because the water was very cloudy, and it could be observed a great amount of suspended solid particles. 
Table 2. Average values of the physical-chemical parameters of the water of the fish farms of the municipality of São Bento- MA, 2010

\begin{tabular}{lcccccc}
\hline Physico-chemical & \multicolumn{7}{c}{ Average by Properties / Standard Deviation } \\
\cline { 2 - 7 } parameters & $\mathrm{A}$ & $\mathrm{B}$ & $\mathrm{C}$ & $\mathrm{D}$ & $\mathrm{E}$ & $\mathrm{F}$ \\
\hline $\mathrm{T}^{\circ} \mathrm{C}$ & $27,4 \pm 0,8$ & $28,9 \pm 0$ & $30 \pm 0$ & $30 \pm 0$ & $28 \pm 0$ & $28 \pm 0$ \\
$\mathrm{Ph}$ & $8,2 \pm 0$ & $5,0 \pm 0$ & $6,0 \pm 0$ & $6,8 \pm 0$ & $7,2 \pm 0$ & $7,4 \pm 0$ \\
Transparency (cm) & $17 \pm 0,83$ & 0 & $19,5 \pm 1,5$ & $31 \pm 10$ & $23,5 \pm 9,5$ & $46 \pm 0$ \\
Turbidity (UNT) & $68,2 \pm 35,23$ & $1.25 \pm 624,35$ & $101,5 \pm 0,5$ & $101,5 \pm 0,5$ & $74,95 \pm 54,05$ & $12 \pm 0$ \\
Color (UH) & $127,96 \pm 60,23$ & 0 & $666,5 \pm 2,5$ & $6,8 \pm 0$ & $190,2 \pm 99,6$ & $108,4 \pm 0$ \\
Oxygen (mg/L) & $14,74 \pm 0,44$ & $7,48 \pm 4,05$ & $14,7 \pm 0$ & $12,45 \pm 2,25$ & $9,8 \pm 4,8$ & $7,1 \pm 0$ \\
Total alkalinity & $266,2 \pm 40,78$ & $412 \pm 63,19$ & $17,5 \pm 3,5$ & $27,5 \pm 6,5$ & $64,8 \pm 20,8$ & $42,4 \pm 0$ \\
(mg/L) & & & & & & \\
Total hardness & $700 \pm 571,23$ & $53,75 \pm 25,38$ & $20 \pm 1$ & $35 \pm 6$ & $59,9 \pm 6,5$ & $14,6 \pm 0$ \\
(mg/L) & $30,82 \pm 26,71$ & $160 \pm 63,63$ & $4 \pm 1$ & $1 \pm 0$ & $55 \pm 5$ & $60 \pm 0$ \\
Nitrate (mg/L) & $0,14 \pm 0,12$ & $0,3 \pm 0,19$ & $0,02 \pm 0,01$ & $0,01 \pm 0$ & $0,5 \pm 0,1$ & $0,3 \pm 0$ \\
Nitrite $(\mathrm{mg} / \mathrm{L})$ & & & & & \\
\hline
\end{tabular}

As for the maximum value reached for turbidity, 1.25 UNT in property B and minimum of $12 \mathrm{UNT}$ in property $\mathrm{F}$ is probably due to the absence of clay content in the bottom of the nursery during the fish harvest (PILARSKI, 2004). The turbidity values found are due to, perhaps, large amounts of sediment observed in soils during the rainy season. According to CONAMA (2005), for class II waters (For the protection of aquatic communities, aquaculture and fishing), is of 100 UNT; The values found in this search, in three properties were above 100 UNT, with the exception of properties; A (68,2 UNT); E (74,95 UNT); F (12 UNT), That were below the allowed range, therefore they are in disagreement with the current Legislation.

Regarding to the water color of the fish farms, the maximum value was 666.5 $\mathrm{UH}$ in the $\mathrm{C}$ property and a minimum of $6.8 \mathrm{UH}$ in the D property, the latter has little organic matter and suspended solids in the water column, favoring the growth of algae And other aquatic organisms, while in property $\mathrm{C}$ there is excess phytoplankton in the body of water.
However, in property $\mathrm{B}$ it was not possible to measure the color of the water, but its turbidity was very high, probably due to the presence of solid sediments contained in the water body.

As for the dissolved oxygen values, these varied at a maximum of $14.74 \mathrm{mg} / \mathrm{L}$, in properties $\mathrm{A}$ and $\mathrm{C}$, resulting from the low amount of fish stored and the excess of phytoplankton in the nurseries, and at least $7.1 \mathrm{mg} / \mathrm{L}$ at property $\mathrm{F}$, because it presents a quantity of fish specimens per square meter, much larger than allowed. Therefore, there is a high consumption of oxygen, especially when the temperature is high, as shown in Table 2. This happens because at the moment fish spend more energy and consume more food. In this parameter, dissolved oxygen, all properties are in accordance with current legislation (CONAMA, 2005), which predicts that the favorable concentrations of dissolved oxygen for fish culture are $5 \mathrm{mg} / \mathrm{L}$ of water. The present work presented high values compared to those obtained by the author (MORAIS, 2015), an oxygenation level of $5 \mathrm{mg} / \mathrm{l}$, on water quality in fish farming: a case study in rural 
communities in the municipality of Formiga ( $\mathrm{MG}$ ).

Regarding to the data for total alkalinity obtained minimum values of $17.5 \mathrm{mg} / \mathrm{L}$, in property $\mathrm{C}$ and in property $\mathrm{B}$ the maximum value was $412 \mathrm{mg} / \mathrm{L}$ Therefore, this value can be attributed to the application of limestone in the nurseries, which added to the soil will react with the water and produce $\mathrm{CO} 2$, contributing to the increase of alkalinity due to the formation of carbonate ions and bicarbonates (SIPAÚBATAVARES, 1995). However, the six properties studied with the exception of property $\mathrm{C}$ presented values over 20 $\mathrm{mg} / \mathrm{L}$ throughout the research, according to technical recommendations for fish farms, as determined by Boyd (1972), which states that the minimum acceptable total alkalinity for a nursery for fish farming to show good fish production is $20 \mathrm{mg} / \mathrm{L}$.

On the other hand, the obtained data in the determination of the total hardness were of maximum $700 \mathrm{mg} / \mathrm{L}$, in the property $\mathrm{A}$, value attributed to the fact that limestone was added two weeks before the samples were obtained and also the water was renewed for the new fingerlings. The minimum hardness content was $14.6 \mathrm{mg} / \mathrm{L}$, at property $\mathrm{F}$, probably due to the absence of limestone. However, the authors, Golombieski et al. (2005) report that total hardness is the concentration of all bivalent cations in water, with calcium $(\mathrm{Ca} 2+)$ and magnesium $(\mathrm{Mg} 2+)$ being the most common cations in almost all freshwater systems. The recommended total hardness value for fish culture in tanks is above $20 \mathrm{mg} / \mathrm{L}$ of $\mathrm{CaCO}_{3}$ (BOYD \& EGNA, 1997).

As for the nitrate levels in the water, there was a difference between the studied properties (Tabela 2). The water samples of properties $\mathrm{C}$ and $\mathrm{D}$ presented values below $5 \mathrm{mg} / \mathrm{L}$, in properties $\mathrm{A}, \mathrm{B}$,
$\mathrm{E}$, and $\mathrm{F}$, the values found were 30 to $160 \mathrm{mg} / \mathrm{L}$, higher than $5 \mathrm{mg} / \mathrm{L}$. In this case, the first two properties (C and D) presented values below the concentration allowed by the current legislation (CONAMA, 2005) for class II waters (maximum of $10 \mathrm{mg} / \mathrm{L}$ ), because in systems of fish farming with high load of organic matter, nitrate generally presents low values, because the system is predominantly organic. Periodic additions of nitrogen (NO3, NO2, NH3 and NH4) should occur in nurseries, in the form of fertilizers or feed, so that the concentrations are maintained high enough for the abundant growth of phytoplankton and, consequently, to obtain higher productivity (BOYD, 1997). The present values of property $C$ and $\mathrm{D}$ are the same as those obtained in the analyzes made in the reservoirs of the water quality of dams used in fish farming in a polyculture system - a case study, nitrate values were much lower than $5 \mathrm{mg} / \mathrm{L}$, during the sampling period, also not presenting a risk to the fish. In relation to the nurseries of property $\mathrm{A}, \mathrm{B}$, $\mathrm{E}$, and $\mathrm{F}$ presented high values to that of the author (CAETANO, 2015).

Nitrite values ranged from 0.01 to 0.45 $\mathrm{mg} / \mathrm{L}$. In nursery E $(0.45 \mathrm{mg} / \mathrm{L})$ there are risks of fish poisoning, but nitrite is considered an intermediate state of the nitrogen cycle, formed during the decomposition of the organic matter, readily oxidized to nitrate, but these processes did not occur in this nursery, probably due to the partial decomposition of organic matter, excessive discharge from stocking density and lack of adequate management (excess of distributed food). The presence of nitrite may indicate the presence of nitrate reducing bacteria when the present conditions are anaerobic (SIPAÚBATARVARES, 1994). The value of nursery $E$ is higher than the value acquired by the research, the influence of 
the water quality of the Pereira de Miranda reservoir on the embryonic development of common carp, nitrite level was of $0,104 \mathrm{mg} / \mathrm{L}$ (LINHARES, 2013).

In the $\mathrm{D}$ property, the minimum nitrite value was $0.01 \mathrm{mg} / \mathrm{L}$, a concentration considered harmless, being in accordance with current legislation (CONAMA, 2005), which recommends that the nitrite level does not exceed 0.5 $\mathrm{mg} / \mathrm{L}$, since it is toxic for fish, because when combined with low chlorine and dissolved oxygen contents, they can cause methemoglobinemia, also known as brown blood disease.

These values in general can be related to the management conditions used in nurseries. We can mention that most nurseries did not receive organic fertilization because nurseries had a depth of $6 \mathrm{~m}^{3}$, In addition, water used in this environment comes from natural streams and rains, now when they received lime vigem, the fish were still there. The owners did not make the water renovation, some nurseries dried due to the dry season. In relation to the type of food provided to the fish, they offered little feed and the rest purchased from the environment. Therefore, the results of the present study emphasize the importance of the monitoring of the physicochemical parameters of the nursery waters.

According to the results obtained and in the conditions under which the research was carried out, it is possible to conclude that the water used in the nurseries of the evaluated fishery presents microbiological and physico-chemical characteristics that are not suitable for use in fish farming. Therefore, the best way to avoid this situation, the execution of an appropriate management according to the situations of all the nurseries. First, it should reduce the depth of the nursery to $1 \mathrm{~m} 3$ for easier handling; Avoiding the presence of domestic animals in fish ponds and overcrowding; knows to correctly use limestone in soil fertilization (recommended 1790 to $0 \mathrm{~kg} / \mathrm{ha}$ of agricultural limestone), aeration should be used as a preventive measure for sudden drop in oxygen; reduce the accumulation of sediments in nurseries transported by surface runoff in the rainy season, in any way, use diversions and stabilization structures around nurseries or maintain good vegetation coverage in all parts of the watershed, and plant a higher vegetation And dense when possible near the nurseries.

\section{ACKNOWLEDGEMENTS}

To the fish farmers of the municipality of São Bento - Maranhão.

To the Laboratory of Microbiology of Food and water of the Center of Agrarian Sciences IUEMA.

To Funasa for allowing me to carry out the analyzes in its Laboratory.

\section{REFERENCES}

AMERICAN PUBLIC HEALTH ASSOCIATION - APHA. Standard methods for the examination of the water and wastewater. $20 \mathrm{ed}$. New York, 2001.

BRASIL. Ministério da Saúde.

Portaria 518, de 25 de março 2004.

Estabelece os procedimentos e responsabilidades relativos ao controle e vigilância da qualidade da água para consumo humano e seu padrão de potabilidade, e dá outras providências.

\section{Diário Oficial da República}


Federativa do Brasil, Brasília, n. 59, 26 mar., 2004.

BOYD, C.E. Water quality in aquaculture. Alabama: Birminghan Publishing Co., 1972. 482p.

BOYD, C.E. Water quality in ponds for aquaculture. Alabama: Bimingham publishing Co., 1990. 482p.

BOYD, C.E.; EGNA, H.I. Dynamics of pond aquaculture. Boca Raton, New York: CRC Press, 1997.

BOYD, C.E. Manejo do solo e da qualidade da água em viveiros para aqüicultura. Alabama: Auburn University, 1997. 55p.

CAETANO, M.S.; PRETO, B.L.; OLIVEIRA, L.B.; AMARAL, A.A. Qualidade da água de açudes utilizados na criação de peixes em sistema de policultivo - um estudo de caso.

Enciclopédia Biosfera, v.11, n.22, p.190, 2015

CONAMA. Revolução no 357 de 17 de março de 2005. Dispõe sobre a classificação dos corpos da água e diretriz ambientais para o seu enquadramento, bem como estabelece as condições e padrões de lançamento de efluentes, e da outras procedências.

Diário Oficial da União, Brasília, 2005. Disponível em:

$<$ http://www.mma.gov.br/port/conama >. Acesso em: 15 out.2009.

GOLOMBIESKI, Jaqueline Ineu et al. Qualidade da água no consórcio de peixes com arroz irrigado. Ciência Rural [online], v.35, n.6, pp. 12631268, 2005.
INSTITUTO BRASILEIRO DE GEOGRAFIA ESTÁTISTICO IBGE. Produção pecuária municipal. Rio de janeiro, 2016.

LINHARES, F.R.A.; NUNES, L.T.; LOPES, J.T.; GALVÃO, J.A.S.; NUNES, J.F.; SALMITOVANDERLEY, C.S.B. Influência da qualidade da água do açude Pereira de Miranda sobre o desenvolvimento embrionário de carpa comum. Ciência Animal, v.23, n.2, p.29-35, 2013.

LORENZON, C. S.; JUNIOR GATTI, P.; NUNES, A.P.; PINTO, F.R.; SCHOLTEN, C.; HONDA, S.N.; AMARAL, L.A. Perfil microbiológico de peixes e água de cultivo em pesquepagues situados na região nordeste do Estado de São Paulo. Arquivos do Instituto Biológico, v.77, n.4, p.617624, 2010.

MORAIS, J.P; RIBEIRO, K.D; COUTINHO, F.P; OLIVEIRA, M.C. Qualidade da água na piscicultura: um estudo de caso em Comunidades rurais do município de formiga - mg. In: SIMPÓSIO BRASILEIRO DE RECURSO HÍDRICO, 21, 2015, Brasília, DF. Anais... Brasília, DF, 2015.

\section{OLIVEIRA, L.S.N. Panorama Geral da Pesca e Aquicultura Mundial. Brasília: Ministério da Pesca e Aquicultura, 2010. 124p ( Boletim Estatístico da Pesca e Aquicultura). \\ PILARSKI, F.; TOMAZELLI JÚNIOR, O.; CASACA, J.deM.; GARCIA, F.R.M,; TOMAZELLI, I.B.; SANTOS, I.R.dos. Consórcio suíno-peixe: aspectos ambientais e qualidade do pescado. Revista Brasileira de Zootecnia, v.33, n.2, 2004.}


SILVA, R.M.L. Bactérias do gênero Aeromonas e indicadores de qualidade da água em piscicultura da Região da baixada Ocidental Maranhense. 2010. 75f. Tese

(Doutorado) - Universidade Estadual Paulista, Faculdade de Ciências Agrárias e Veterinárias, Jaboticabal.

SIPAÚBA-TAVARES, L.H.

Limonologia aplicada á aqüicultura. Jaboticabal: FUNEP,1994. 70p.

SIPAÚBA-TAVARES, L.H. Influência da luz, manejo e tempo de residência sobre algumas variáveis limnológicas em um viveiro de piscicultura.

Biotemas, v.8, n.1, p.61-71, 1995.

Data de recebimento: 19/10/2016

Data de apresentação: 19/06/2017 